\title{
Quantitative Analysis of some Germplasms of lablab Bean in Uttar Pradesh
}

\author{
Arvind Kumar
}

Department of Botany, Raja Balwant Singh College, Khandari, Agra, U.P., India

\begin{abstract}
Lablab purpureus (L.) sweet is an ancient multipurpose legume that combines use as human food and forage in addition to serving as a cover crop for soil conservation. The crop is believed to be cultivated in south India as early as $1400-1500$ BC. Although wide variability for agro-morphological traits exists in India, a more extensive germplasm collection and evaluation has not been reported so far. Hence the present study was undertaken with a set of 50 lablab accessions mainly collected from south India including nine accessions of exotic origin. All the 50 accessions were characterized for 29 qualitative and 10 quantitative traits. Further, there exists very high genetic differentiation between the exotic and the lines of Indian origin as also evident from biplot and scatter plot analysis. Although the exotic lines deviated for the Indian lines for majority of the traits, much of the useful variation for genetic improvement of vegetable traits existed among the Indian accessions while, the exotic lines possessed traits of forage importance.
\end{abstract}

Keywords - Lablab purpureus, genetic structure, exotic accessions, genetic variability.

\section{INTRODUCTION}

Lablab bean or field bean or dilichos bean (Lablab purpureus L. sweet) is one of the ancient multipurpose crops widely distributed in India. Africa and South East Asia (Maass et al.2005). The crop is predominantly grown for grain, vegetable and fodder. Studies in Lablab have shown that the perennial types have considerable genetic and morphological diversity. For its use as pulse, white or cream coloured seeds are preferred over dark seed types. The most preferred types for vegetable are long pods, bold seeded with high pod fragrance. Cultivars with high biomass yield and drought tolerance are mostly suited for forage purposes. The crop has also been used as garden plant in USA for generations due to its beautiful dark green purple veined foliage with large spikes clustered with deep violet and white pea like blossoms. Lablab bean is better adapted to drought conditions as compared to common bean (Phaseolus vulgaris) and cowpea (Vigna unguiculata). The Rongai cultivar was derived from Rongai distric of Kenya and released in Australia in 1962 (Wilson and Murtagh 1962) the crop is adaptable to diverse climate conditions such as arid, semiarid, sub-tropical and humid conditions. In India, it is concentrated in the peninsular region and is cultivated in Karnataka, Tamil Nadu, Maharashtra and Andhra Pradesh.

Sufficient agro-morphological variation for yield and its attributes is found in Indian accessions but molecular diversity studies conducted with a set of 62 Indian accessions using AFLP and EST-SSR markers revealed narrow genetic diversity (Venkatesha et al.2007). Substantial variation for adro-morphological traits among lablab accessions was reported (Uddin and Newaz 1997, Mahadevu and Byre Gowda 2005, Islam 2008, Savitha and Ravikumar 2009, Girish and Byregowda 2009, Mohan et al.2009, Latha et al.2009, Upadhyay and Mehta 2010). Research information on this crop is not widwspread and scattered in a limited number of journal and reports. Despite its wide distribution in the Asian and African countries it is still considered a neglected crop with underused potential. For use as a legume, vegetable or forage crop, an understanding of available genetic diversity is the first step for future crop improvement. Information on genetic diversity and population structure is pre-requisite for planning breeding programs as it assists in choosing of divergent parents for crossing, providing more rational basis for expanding genes pool and for identifying genotypes that harbor valuable genes for its incorporation in breeding programs. Moreover, understanding the genetic structure in the populations facilitates appropriate genetic conservation strategies (Bhosale et al.2011). a better utilization and a fuller exploitation of collected materials required better knowledge of the variability existing among the collections. Therefore the present study was aimed at accessing patter of variation among the 50 Indian and exotic accessions for 10 quantitative and 29 qualitative traits, genetic structure among the accession and to identify trait relationship for important yield attributing traits.

\section{MATERIALS AND METHODS}

\subsection{Genetic materials}

A total of 50 lablab accessions were used in the present study. All the 50 germplasm accessions were raised in 
augmented design at the R. B. S. College, Agriculture Dept. Bichpuri, Agra, Uttar Pradesh, India. Each accession was sown as single rows of $3 \mathrm{M}$ length with inter row spacing of $60 \mathrm{~cm}$ and $15 \mathrm{~cm}$ between plants. All recommended package as per the requirement of the crop was adopted. Observations were recorded on 29 qualitative characters (table 1) and 10 quantitative characters (days to $50 \%$ flowering, plant height $(\mathrm{cm})$, pods per plant, green pod yield per plant $(\mathrm{g})$, dry seed yield per plant $(\mathrm{g})$, days to maturity, seeds per pod, 100 seed weight (fresh and dry), shall recovery percent (dry) based on the descriptors provided by the International Plant Genetic Resources Institute.

\section{RESULTS AND DISCUSSION}

\subsection{Frequency distribution for qualitative traits}

\subsubsection{Seedling and plant characteristics}

The frequency distribution for 29 qualitative traits is given in table 1 . The emerging cotyledon colour was observed green in $40(13.08 \%)$ accessions and white in 10 $(1.92 \%)$ accessions. The hypocotyl colour was observed to be white in all the 50 accessions. Majority of the accessions $38(13.22 \%)$ were found to be non-pigmented, whereas, $8(0.438 \%)$ extensively pigmented. In $3(1.33 \%)$ accessions, the stem pigmentation was found to be almost solid and in $1(0.12 \%)$ accessions, it was localized nodes. The growth habit was observed to be intermediate in 44 $(14.60 \%)$ accessions while $6(0.40 \%)$ were found to be determinate. With regard to branch orientation, 27 $(11.33 \%)$ accessions possessed branches tending to be perpendicular to main stem while, $4(1.33 \%)$ were found to have short and erect lateral branches.

\subsubsection{Leaf characteristics}

The vein colour of fully developed primary leaves was observed to be green in $48(13.50 \%)$ of the individuals while, $2(1.50 \%)$ recorded purple colour. The leaf anthocyanin was absent in all the 50 accessions studied. Leaves of almost half the number of accessions 22 $(7.23 \%)$ were pale green while, $28(7.77 \%)$ were observed to be green. High variation was observed for leaf hairiness. The number of accessions belonging to glabrous group were $20(5.58 \%)$ while, $26(8.39 \%)$ individuals possessed low pubescence and 4 accessions $(1.03 \%)$ were moderately pubescent. A total of 45 $(14.06 \%)$ accessions possessed round leaf shape, 2 $(0.12 \%)$ ovate and $3(0.82 \%)$ ovate-lanceolate. Leaf persistence was observed when $90 \%$ pods were ripened. A total of $45(12.61 \%)$ accessions were classified under most leaves remaining category.

\subsubsection{Flower characteristics}

Wide variability was observed for flower bud colour. The flower bud colour recorded white in $2(1.00 \%)$ accessions, cream in $39(11.00 \%)$ accessions, light yellow in 1
$(0.52 \%)$ accessions, pink in $6(1.48 \%)$ accessions and purple in $2(1.00 \%)$ accessions. The standard petal colour, wing petal colour and keel petal colour were white in 40 $(13.06 \%)$ accessions, pink in $7(0.94 \%)$ and purple in 3 $(1.00 \%)$ accessions respectively.

\subsubsection{Pod characteristics}

The pod curvature was observed straight in 20 accessions, slightly curved in 20 accessions respectively. High variability was observed for pod pubescence, one of the most important character which attributes to resistance for insect pests. Maximum numbers of accessions (42) were found to be moderately pubescent, 1 were found to be pubescent and 7 accessions were found to be glabrous. Pod beak was recorded short in 7 accessions, medium in 4 , long in 38 and thick in 1 accessions. Pod fragrance is one of the characters influencing consumer acceptability. Pod fragrance was estimated to be absent in 3 individuals, low in 7 , medium in 30 and 10 accessions with high fragrance. With respect to constriction on the pods, most of the accessions (45) were slightly constricted while, 4 accessions constricted and 6 accessions have no constriction. The distribution of pod colour was $0.28 \%$ as white, $1.06 \%$ in cream, $12.26 \%$ in green, $0.56 \%$ in green with purple stature and $0.28 \%$ purple. Erect type of pod attachment was observed in 19 accessions, 30 with intermediate and 1 accession with pendent type. Pod attachment at maturity was found to be erect in 10 accessions, 35 with intermediate and 5 with pendant type.

\subsubsection{Seed characteristics}

Almost all the individuals (48) recorded green seed colour on fresh seeds, while fresh seeds of 1 and 1 accessions recorded cream and purple colour respectively. Oval seed shape (46) was found to be dominant over the round seed shape (4). Seed colour at maturity was observed to be green in maximum of accessions whereas, only 9 and 1 accessions recorded cream and white colour respectively. The dry seed colour was found to be highly variable as compare to the fresh seed colour. A total of individuals had 20 cream colour, 5 purple, 19 brown, 4 black and 1 green in colour. The seed shape of the dry seeds was classified as oval in a total of 25 accessions, round in 20 accessions; only one accession was classified under flat category. No variability was recorded for seed texture at maturity and all the accessions (50) were found to be moderately ridged.

\section{CONCLUSIONS}

50 lablab accessions sown as single rows of $3 \mathrm{M}$ length with inter row spacing of $60 \mathrm{~cm}$ and $15 \mathrm{~cm}$ between plants were observed for 10 quantitative characters (days to $50 \%$ flowering, plant height $(\mathrm{cm})$, pods per plant, green pod yield per plant $(\mathrm{g})$, dry seed yield per plant $(\mathrm{g})$, days to maturity, seeds per pod, 100 seed weight (fresh and 
dry), dhall recovery percent (dry) based on the descriptors provided by the International Plant Genetic Resources Institute.They were found to be different and are promising candidates for breeding.

\section{REFERENCES}

[1] Bhosale SU, Stich B, Rattunde HFW, Weltzien E, Haussmann BIG, Hash CT, Melchinger AE and Parzies HK (2011). Population structure in sorghum accessions from West Africa differing in race and maturity class. Genetic 139:453-463.

[2] Das LDV (1990). Performance of forage accessions of Dolichos lablab (L.) Madras Agricultural Journal 77:555-556.

[3] Earl DA (2011). Structural harvester v0.6.1. http://taylor0.biology.ucla.edu/structureHarvester/Ac cessed 5 Dec 2012.

[4] Elangaimannan R, Anbuselvam $Y$ and Karthikeyan $P$ (2008). Genetic diversityin blackgram [Vigna mungo 9L.0 hepper]. Legume Res 31:57-59.

[5] Evanno G. Reagnaut S and Goudet J (2005). Detecting the number of clusters of individuals using the software STRUCTURE: a stimulation study. Molecular Ecology 14:2611-2620.

[6] Falush D, Stephens M and Pritchard JK (2007). Inference of population structure using multilocus genotype data: dominant markers and null alleles. Molecular Ecology Notes 7:574-578.

[7] Fuller DQ and Harvey EL (2006). The archaeobotany of Indian pulses: Identification, processing and evidence for cultivation. Environ Archaeol 11:220246.

[8] Fuller DQ, Korisettar R, Venkatasubbaiah PC and MK Jhones (2004). Early plant domestications in southern India: some preliminary archaeobotanical results. Vegetation Hist Archaeobot 13:115-129.

[9] Girish G and Byre Gowda M (2009). Inheritance of qualitative characters in Dolichos bean Lablab purpureus L. Sweet. Environ Ecol 27:571-580.

[10] Hartl DL and Clark AG (1997). Principles of population genetics. $3^{\text {rd }}$ Edition. Sinauer Associates, Inc. Publishers, Sunderland, Massachusetts, USA

[11] Islam MT (2008). Morpho-agronomic diversity of hyacinth bean (Lablab purpureus (L.) Sweet) accessions from Bangladesh. Plant Genetics Resourses Newsletter 156:72-77.

[12] Kimani EN, Wachira FN and Kinyua MG (2012). Molecular diversity of Kenyan lablab bean(Lablab purpureus (L.) Sweet) accessions using amplified fragment length polymorphism marker. American J Plant Sci 3:313-321.

[13] Lablab bean website (http://www/lablab.org)
[14] Latha M, Mani S, Lissy MB, Abraham Z, Asokan NR, Hanuman L and Mishra SK (2009). Collection and characterization of field bean (Lablab purpureus (L.) Sweet var. purpureus ) Indian J Plant Genet Resou 22:93-97.

[15] Liu CJ (1996). Genetic diversity and relationships among Lablab purpureus genotypes evaluated using RAPD as markers. Euphytica 90:115-119.

[16] Maass BL, Jamnadass RH, Hanson J and pengelly BC (2005).determining sources of diversity in cultivated and wild Lablab purpureus related to provenance of germplasm by using amplified fragment length polymorphism. Lablab purpureus (L.) 52:683-695.

[17] Maass BL, Knox MR, Venkatesha SC, Angessa TT, Ramme S and Pengelly BC (2010) Lablab purpureus - A crop lost for Africa? Tropical Plant Biology 3:123-135.

[18] Mahadevu P and Byre Gowda M (2005). Genetic improvement of Dolichos bean (Lablab purpureus (L.) Sweet) through use of exotic and indigeneous germplasm. Indian J Plant Genetic Resources 18:4748.

[19] Mohan N, Aghora TS and Devraju (2009). Evalution of dolichos (Lablab purpureus L.) germplasm for pod yield and pod related traits. J Hort Sci 4:50-53.

[20] Nadarajan N and Gunasekaran M (2005). Basic principles In: Quantitative genetics and biomaterical techniques in plant breeding. Kalyani Publishers, New Delhi.

[21] Prakash P, Venkatesha SC, Ashok TH, Gowda TKS, Byre Gowda M (2009). Genetic diversity in field bean as revealed with AFLP markers. J Food Legumes 22:18-22

[22] Pengelly BC and BL Maass (2001). Lablab purpureus (L.) Sweet- diversity, potential use and determination of a core collection of this multipurpose tropical legume. Genetic Resources Crop Evol 48:26-272.

[23] Pritchard JK, Stephens M and Donnelly P (2000). Inferences of population structure using multilocus genotype data. Genetics 155:945-959.

[24] Savitha BN and Ravikumar RL (2009). Comparative analysis of phenotypic and molecular diversity in selected pendal and non-pendal genotypes of field bean [Lablab purpureus (L.) Sweet]. Indian J Plant Genetic Resources 69:232-236.

[25]STRUCTURE software pakage (http://pritch.bsd.uchicago.edu/structure.html)

[26]STRUCTURE Harvester online program (http://taylor0.biology.ucla.edu/structureHarvester)

[27] Uddin MS and Newaz MA (1997). Genetic parameters and the association among flower and pod 
characteristics of hyacinth bean. Legume Res 20:8286.

[28] Upadhyay D and Mehta N (2010). Biometrical studies in Dolichos Bean ( Dolichos lablab L.) for Chhattisgarh plains. Research J Agric sci 1:441-447

[29] Ushakumari R and chandrasekharan P (1992). Genetic variability and correlation studies in fodder lablab (Lablab purpureus (L.) Indian J Genet plant Breed 52:169-173.

[30] Venkatesha SC, byre Gowda M, Mahadevu P, Mohan Rao, Kim DJ, Ellis N and Knox MR (2007). Genetic diversity within Lablab purpureus and the application of gene specific marker from a range of legume species. Plant Genetic resour 5:154-171.

[31] Whitbread AM, Pengelly BC (eds) (2004). Tropical legumes for sustainable farming systems in southern Africa and Australia. ACIAR Proc.no.115, Canberra, Australia, Pp 180.

[32] Wilson G P, Murtagh GJ (1962) Lablab - New forage crop for the north coast. New south Eales agricultural Gazette 73:460-462.

[33] Wright S (1978) Evolution and the genetics of populations vol 4. Variability within and among natural populations, University of Chicago Press, Chicago, Pp 580.

Table.1: Characterization of lablab accessions using descriptors provided by the international plant Genetic resources Institute.

\begin{tabular}{|c|c|c|c|c|c|}
\hline S.No & Character & State of Expression & Score & $\begin{array}{c}\text { No. of } \\
\text { accessions }\end{array}$ & Frequency \\
\hline \multirow[t]{3}{*}{1} & Emerging cotyledon colour & White & 1 & 10 & 1.92 \\
\hline & & Green & 2 & 40 & 13.08 \\
\hline & & purple & 3 & 0 & 0.00 \\
\hline \multirow[t]{2}{*}{2} & Hypocotyl colour & White & 1 & 50 & 15.00 \\
\hline & & green & 2 & & 0.00 \\
\hline \multirow[t]{4}{*}{3} & Stem pigmentation & No pigmentation & 0 & 38 & 13.2 \\
\hline & & Localized to nodes & 3 & 1 & 0.12 \\
\hline & & Extensive & 5 & 8 & 0.438 \\
\hline & & Almost solid & 7 & 3 & 1.33 \\
\hline \multirow[t]{2}{*}{4} & $\begin{array}{l}\text { Vein colour (fully developed } \\
\text { primary leaves, on inner face) }\end{array}$ & Green & 1 & 48 & 13.50 \\
\hline & & Purple & 2 & 2 & 1.50 \\
\hline \multirow[t]{2}{*}{5} & Leaf anthrocyanin & Absent & 0 & 50 & 15.00 \\
\hline & & present & 2 & & 0.00 \\
\hline \multirow[t]{2}{*}{6} & Leaf colour & Pale green & 1 & 22 & 7.23 \\
\hline & & Green & 3 & 28 & 7.77 \\
\hline \multirow[t]{4}{*}{7} & Leaf hairiness & Glabrous & 0 & 20 & 5.58 \\
\hline & & Low pubescent & 3 & 26 & 8.39 \\
\hline & & Moderately pubescent & 5 & 4 & 1.03 \\
\hline & & Highly pubescent & 7 & 0 & 0.0 \\
\hline \multirow[t]{5}{*}{8} & Leaf shape & Round & 1 & 45 & 14.06 \\
\hline & & Ovate & 3 & 2 & 0.12 \\
\hline & & Ovate-lanceolate & 5 & 3 & 0.82 \\
\hline & & Lanceolate & 7 & & 0.0 \\
\hline & & Linear- lanceolate & 9 & & 0.0 \\
\hline \multirow[t]{3}{*}{9} & $\begin{array}{l}\text { Leaf persistence (when } 90 \% \text { pods } \\
\text { are ripe) }\end{array}$ & Few leaves remaining & 3 & 45 & 12.61 \\
\hline & & Intermediate & 5 & & 0.00 \\
\hline & & Most leaves remaining & 7 & 5 & 2.39 \\
\hline \multirow[t]{4}{*}{10} & Growth habit & Determinate & & 6 & 0.40 \\
\hline & & Semi-determinate & 2 & & 0.00 \\
\hline & & Indeterminate & 3 & 44 & 14.60 \\
\hline & & Others (specify) & 4 & & 0.00 \\
\hline
\end{tabular}




\begin{tabular}{|c|c|c|c|c|c|}
\hline \multirow[t]{3}{*}{11} & Branch orientation & $\begin{array}{l}\text { Short and erect lateral } \\
\text { branches }\end{array}$ & 3 & 4 & 1.33 \\
\hline & & $\begin{array}{l}\text { Branches tending to be } \\
\text { perpendicular to main } \\
\text { stem, medium in } \\
\text { length }\end{array}$ & 5 & 27 & 11.33 \\
\hline & & $\begin{array}{l}\text { First lateral branches } \\
\text { long and spreading } \\
\text { over ground }\end{array}$ & 7 & 19 & 2.34 \\
\hline \multirow[t]{5}{*}{12} & Flower bud colour & White & 1 & 2 & 1.00 \\
\hline & & Cream & 2 & 39 & 11.00 \\
\hline & & Light yellow & 3 & 1 & 0.52 \\
\hline & & Pink & 4 & 6 & 1.48 \\
\hline & & purple & 5 & 2 & 1.00 \\
\hline \multirow[t]{5}{*}{13} & Standard petal colour & White & 1 & 40 & 13.06 \\
\hline & & Cream & 2 & & 0.00 \\
\hline & & Light yellow & 3 & & 0.00 \\
\hline & & Pink & 4 & 7 & 0.94 \\
\hline & & purple & 5 & 3 & 1.00 \\
\hline \multirow[t]{5}{*}{14} & Wing petal colour & White & 1 & 40 & 13.06 \\
\hline & & Cream & 2 & & 0.00 \\
\hline & & Light yellow & 3 & & 0.00 \\
\hline & & Pink & 4 & 7 & 1.00 \\
\hline & & purple & 5 & 3 & 0.94 \\
\hline \multirow[t]{5}{*}{15} & Keel petal colour & White & 1 & 40 & 13.06 \\
\hline & & Cream & 2 & & 0.00 \\
\hline & & Light yellow & 3 & & 0.00 \\
\hline & & Pink & 4 & 7 & 1.00 \\
\hline & & purple & 5 & 3 & 0.94 \\
\hline \multirow[t]{3}{*}{16} & Pod curvature & Straight & 0 & 20 & 5.10 \\
\hline & & Slightly curved & 3 & 20 & 4.00 \\
\hline & & Curved & 5 & 10 & 5.90 \\
\hline \multirow[t]{3}{*}{17} & Pod pubescence & Glabrous & 0 & 7 & 1.00 \\
\hline & & Moderately pubescent & 3 & 42 & 13.39 \\
\hline & & Pubescent & 5 & 1 & 0.61 \\
\hline \multirow[t]{4}{*}{18} & Pod beak & Short beak & 1 & 7 & 3.00 \\
\hline & & Medium beak & 2 & 41 & 0.66 \\
\hline & & Long beak & 3 & 38 & 11.22 \\
\hline & & Thick beak & 4 & 1 & 0.12 \\
\hline \multirow[t]{4}{*}{19} & Pod fragrance & Absent & 0 & 3 & 0.38 \\
\hline & & Low & 1 & 7 & 3.56 \\
\hline & & Medium & 2 & 30 & 10.06 \\
\hline & & high & 3 & 10 & 1.00 \\
\hline \multirow[t]{3}{*}{20} & Pod constriction & No constriction & 0 & 1 & 0.78 \\
\hline & & Slightly constricted & 3 & 45 & 13.22 \\
\hline & & constricted & 5 & 4 & 1.00 \\
\hline \multirow[t]{4}{*}{21} & Pod colour & White & 1 & 1 & 0.28 \\
\hline & & Cream & 2 & 3 & 1.06 \\
\hline & & Green & 3 & 43 & 12.26 \\
\hline & & $\begin{array}{l}\text { Green with purple } \\
\text { suture }\end{array}$ & 4 & 1 & 0.56 \\
\hline
\end{tabular}




\begin{tabular}{|c|c|c|c|c|c|}
\hline & & Purple & 5 & 1 & 0.28 \\
\hline & & Dark purple & 6 & 1 & 0.56 \\
\hline & & Red & 7 & & 0.00 \\
\hline \multirow[t]{3}{*}{22} & Pod attachment & Erect & 1 & 19 & 6.78 \\
\hline & & Intermediate & 2 & 30 & 7.94 \\
\hline & & Pendent & 3 & 1 & 0.28 \\
\hline \multirow[t]{3}{*}{23} & Pod attachment at maturity & Erect & 1 & & 3.11 \\
\hline & & Intermediate & 2 & 35 & 10.28 \\
\hline & & Pendent & 3 & & 1.61 \\
\hline \multirow[t]{5}{*}{24} & Seed colour (fresh) & Green & 1 & 48 & 14.16 \\
\hline & & Cream & 2 & 1 & 0.56 \\
\hline & & Purple & 3 & 1 & 0.28 \\
\hline & & Brown & 4 & & 0.00 \\
\hline & & Black & 5 & & 0.00 \\
\hline \multirow[t]{4}{*}{25} & Seed shape (fresh) & Round & 1 & 4 & 3.06 \\
\hline & & Oval & 2 & 46 & 11.94 \\
\hline & & Flat & 3 & & 0.00 \\
\hline & & Others (specify) & 4 & & 0.00 \\
\hline \multirow[t]{6}{*}{26} & Seed colour at maturity & White & 1 & 1 & 0.56 \\
\hline & & Green & 2 & 40 & 10.28 \\
\hline & & Cream & 3 & 9 & 4.72 \\
\hline & & Purple & & & 0.00 \\
\hline & & Brown & & & 0.00 \\
\hline & & Black & & & 0.00 \\
\hline \multirow[t]{5}{*}{27} & Seed colour (dry) & Green & 1 & 1 & 0.83 \\
\hline & & Cream & 2 & 20 & 4.61 \\
\hline & & Purple & 3 & 5 & 1.17 \\
\hline & & Brown & 4 & 19 & 6.28 \\
\hline & & Black & 5 & 4 & 2.11 \\
\hline \multirow[t]{4}{*}{28} & Seed shape (dry weight) & Round & 1 & 20 & 6.78 \\
\hline & & Oval & 2 & 25 & 8.22 \\
\hline & & Flat & 3 & 1 & 0.28 \\
\hline & & Others (specify) & & & 0.00 \\
\hline \multirow[t]{3}{*}{29} & Seed texture at maturity & Smooth & 3 & & 0.00 \\
\hline & & Moderately ridged & 5 & 50 & 15.00 \\
\hline & & Markedly ridged & 7 & & 0.00 \\
\hline
\end{tabular}

